\title{
PENGARUH KEPEMIMPINAN TRANSFORMASIONAL, BUDAYA ORGANISASI, PROGRAM KESELAMATAN DAN KESEHATAN KERJA TERHADAP KEPUASAN KERJA KARYAWAN
}

\author{
I Komang Adi Karmawan ${ }^{1}$ \\ I Gde Adnyana Sudibya ${ }^{2}$ \\ ${ }^{1,2}$ Fakultas Ekonomi dan Bisnis Universitas Udayana, Bali, Indonesia \\ email: adikarmawan01@gmail.com
}

\begin{abstract}
ABSTRAK
Kepuasan kerja karyawan merupakan faktor yang sangat penting dalam sebuah perusahaan atau organisasi. Tujuan penelitian ini adalah untuk menganalisis pengaruh gaya kepemimpinan transformasional, budaya organisasi, program keselamatan dan kesehatan kerja terhadap kepuasan kerja karyawan. Populasi dalam penelitian ini adalah karyawan PT Pos Indonesia Denpasar tahun 2016 sebanyak 305 orang. Metode pengambilan sampel dalam penelitian ini menggunakan proportionate stratified random sampling. Metode pengumpulan data yang digunakan dalam penelitian ini adalah observasi, wawancara dan kuesioner. Teknik analisis yang digunakan adalah Analisis faktor konfirmatori, analisis regresi linier berganda, uji asumsi klasik dan pengujian hipotesis. Hasil penelitian ini menunjukkan bahwa kepemimpinan transformasional, budaya organisasi, program keselamatan dan kesehatan kerja berperngaruh positif terhadap kepuasan kerja.

Kata Kunci: kepemimpinan transformasional, budaya organisasi, program keselamatan dan kesehatan kerja, kepuasan kerja
\end{abstract}

\begin{abstract}
Employee satisfaction is a very important factor in a company or organization. The purpose of this study was to analyze the effect of transformational leadership style, organizational culture, occupational safety and health programs on employee job satisfaction. The population in this study were employees of PT Pos Indonesia Denpasar in 2016 as many as 305 people. The sampling method in this study used proportionate stratified random sampling. Data collection methods used in this study were observation, interviews and questionnaires. The analysis technique used is confirmatory factor analysis, multiple linear regression analysis, classical assumption test and hypothesis testing. The results of this study indicate that transformational leadership, organizational culture, occupational safety and health programs have a positive effect on job satisfaction.

Keywords: transformational leadership, organizational culture, safety programs and occupational health, job satisfaction
\end{abstract}




\section{PENDAHULUAN}

Persaingan bisnis dalam era globalisasi menjadi sangat tajam pada semua bidang usaha, baik usaha di pasar domestik maupun di pasar internasional. Dengan memiliki kemampuan bersaing, suatu perusahaan dapat memperoleh keunggulan bersaing (competitive advantage). Persaingan terjadi pada semua industri baik manufaktur maupun jasa. Bersaing dan berhasil dalam lingkungan global yang dinamis berarti sumber-sumber daya yang dimiliki haruslah inovatif selalu siap untuk menanggapi perubahan yang cepat. Dalam pasar tenaga kerja, manajer yang tidak memahami perilaku manusia dan gagal memperlakukan karyawan dengan baik, berisiko kehilangan semua karyawannya. Tantangan bagi manajer adalah menstimulasi kreativitas dan daya tahan karyawan mereka terhadap perubahan. Bidang manajemen sumber daya manusia memberikan banyak ide dan teknik untuk membantu merealisasikan tujuan-tujuan ini.

Sumber Daya Manusia (SDM) adalah faktor sentral dalam suatu organisasi. Apapun bentuk serta tujuannya, organisasi dibuat berdasarkan visi untuk kepentingan manusia dan dalam pelaksanaan misinya dikelola dan diurus oleh manusia. Manajemen sumber daya manusia merupakan suatu perencanaan, pengorganisasian, pengkoordinasian, pelaksanaan, dan pengawasan terhadap pengadaan, pengembangan, pemberian balas jasa, pengintegrasian, pemeliharaan, dan pemisahan tenaga kerja dalam rangka mencapai tujuan organisasi (Mangkunegara, 2010).

Richard et al. (2012) menegaskan bahwa kepuasan kerja (job satisfaction) berhubungan dengan perasaan atau sikap seseorang mengenai pekerjaan itu sendiri, gaji, kesempatan promosi atau pendidikan, pengawasan, rekan kerja, beban kerja dan lain-lain. Kepuasan kerja berhubungan dengan sikap seeorang mengenai kerja, dan ada beberapa alasan praktis yang membuat kepuasan kerja merupakan konsep yang penting bagi pemimpim. Penelitian menunjukkan pekerja yang puas lebih cenderung bertahan bekerja untuk organisasi. Pekerja yang puas juga cenderung terlibat dalam perilaku organisasi yang melampaui deskripsi tugas dan peran mereka, serta membantu mengurangi beban kerja dan tingkat stress anggota dalam organisasi. Pekerja yang tidak puas cenderung bersikap menentang dalm hubungannya dengan kepemimpinan dan terlibat dalam berbagai perilaku yang kontraproduktif.

Salah satu yang dapat mempengaruhi kepuasan kerja karyawan adalah pemimpin. Kepuasan dari diri karyawan tidak akan terbangun tanpa adanya peran pemimpin itu sendiri dalam memberikan motivasi, karena karyawan tidak akan mempunyai semangat dalam melakukan pekerjaan dan hal itu akan sangat mempengaruhi kepuasan kerjanya (Amaliyah dkk., 2014). Penelitian tentang kepemimpinan lebih ditekankan pada kepemimpinan transformasional. Kepemimpinan transformasional pada prinsipnya dapat memotivasi bawahan untuk berbuat lebih baik dari pada yang biasa dilakukan, dengan kata lain dapat meningkatkan kepercayaan. Kepemimpinan transformasional dapat dilihat ketika para pemimpin dan pengikut membuat satu sama lain untuk meningkatkan moral dan motivasi Melalui kekuatan visi dan kepribadian mereka, pemimpin transformasional mampu menginspirasi pengikutnya untuk mengubah harapan, persepsi dan motivasi untuk bekerja menuju tujuan bersama. Situasi organisasi 
dengan kepemimpinan transformasional membuat karyawan selalu bergairah dalam bekerja. Selalu ada sesuatu yang baru dan membuat karyawan akan mendapatkan prestasi yang menggembirakan.

Selain gaya kepemimpinan transformasional, faktor lain yang dapat mempengaruhi kepuasan kerja karyawan, salah satunya adalah budaya organisasi. Menurut Syauta (2012) budaya organisasi adalah pola asumsi dasar yang diciptakan, ditemukan, atau dikembangkan oleh kelompok tertentu ketika mereka mengadaptasi diri dengan masalah-masalah eksternal dan internal sehingga mereka dapat bekerja dengan baik. Pembentukan budaya organisasi yang kuat membutuhkan suatu proses karena perubahan yang terjadi dalam organisasi menyangkut perubahan orang-orang yang berada dalam organisasi termasuk di dalamnya perbedaan persepsi, keinginan, sikap, dan perilaku.

Penelitian serupa oleh Rizondra (2013) dan Hermawan (2015) juga memperoleh hasil bahwa terdapat pengaruh signifikan positif antara budaya organisasi dengan kepuasan kerja, yakni jika semakin tinggi budaya organisasi yang ada pada pegawai maka akan semakin tinggi tingkat kepuasan kerja yang dirasakan oleh pegawai, sebaliknya jika budaya organisasi pegawai rendah dalam bekerja maka semakin turun juga kepuasan yang akan dimiliki dalam bekerja. Maksud dari pernyataan tersebut adalah Budaya Organisasi dirancang oleh perusahaan untuk memacu kinerja karyawan sehingga nantinya perusahaan akan memberikan penghargaan dan tujuannya adalah agar karyawan merasa puas akan pekerjaannya dan perusahaan tempat mereka bekerja.

Faktor penting lainnya yang dapat mempengaruhi tingkat kepuasan kerja kayawan adalah adanya program keselamatan dan kesehatan kerja. Keselamatan dan kesehatan kerja saat ini menjadi kewajiban dan kebutuhan perusahaan dalam segala bentuk kegiatan pekerjaan. Keselamatan dan kesehatan kerja merupakan salah satu bentuk upaya untuk menciptakan tempat kerja yang aman, sehat, bebas dari pencemaran lingkungan, sehingga dapat melindungi karyawannya dari kecelakaan kerja. Ketentuan mengenai keselamatan kerja dan kesehatan kerja diatur dalam Undang-Undang RI No 3 Tahun 2003 dinyatakan bahwa setiap pekerja atau buruh mempunyai hak untuk memperoleh perlindungan atas keselamatan dan kesehatan kerja, moral, dan kesusilaan dan perlakuan yang sesuai dengan harkat dan martabat serta nilai-nilai agama. Menurut Ardana \& Mujiati (2012) keselamatan dan kesehatan kerja (K3) adalah upaya perlindungan yang ditujukan agar tenaga kerja dan orang lain di tempat kerja atau selalu dalam keadaan selamat dan sehat sehingga setiap sumber produksi dapat digunakan secara aman dan efisien.

Sebagai tempat penelitian adalah salah satu cabang PT Pos Indonesia (Persero) yaitu PT Pos Indonesia Denpasar yang mengelola jasa hantaran pos nasional dengan tujuan profit oriented. PT Pos Indonesia Denpasar membagi produk yang ditawarkan ke pelanggan dalam tiga kelompok produk, yaitu core product, expanded product dan extended product. Core Product mencakup tiga jenis layanan, yaitu : standart priority dan customized yang berlaku untuk tiaptiap core business, yaitu komunikasi, logistik dan layanan keuangan. Expanded Product meliputi dua jenis layanan, yaitu ritel dan internet service provider (ISP) melalui wasantara-net. Sementara Extended Product mencakup tiga layanan, yaitu 
produk filateli, logistik pos dan finansial. Agar tiga kelompok produk terus berkembang maka perusahaan perlu meningkatkan performa kinerja karyawan untuk mencapai keberhasilan tujuan perusahaan. PT Pos Indonesia Denpasar dalam operasional usahanya didukung oleh 305 orang karyawan, yang dipimpin oleh 1 orang Kepala Kantor dan 1 orang Manajer Operasional.

Gaya kepemimpinan transformasional di PT Pos Indonesia Denpasar pada dasarnya bisa menyelaraskan diri dengan perubahan situasi. Pimpinan menginspirasi karyawan melalui visinya dengan menetapkan standar kinerja yang tinggi pada bawahan, mempunyai ide-de yang inofatif dan dalam menyelesaikan permasalahan dan memiliki kemampuan berhubungan dengan bawahan (human skill). Berdasarkan kenyataan yang terjadi, dapat dijelaskan beberapa masalah yang terjadi berkaitan dengan gaya kepemimpinan transformasional. Pimpinan kurang berani menerapkan konsep dan prosedur kerja yang baru, padahal konsep dan prosedur kerja yang dijalankan selama ini dirasakan sudah tidak sesuai dengan situasi dan kondisi yang ada. Pimpinan lebih sering memberikan tugas tertentu yang memberikan tantangan kepada beberapa orang karyawan yang dipercayainya, walaupun ada karyawan lain yang punya kemampuan memadai dalam menyelesaikan tugas yang diberikan. Campur tangan pimpinan yang berlebihan sampai ke aspek teknis pekerjaan, namun hanya berupa usulan dan terkadang perintah yang tidak disertai praktek sehingga mengganggu proses kerja dan berdampak pada menurunnya kualitas kerja.

Pemimpin transformasional seharusnya dapat memberikan keteladanan sebagai panutan bagi karyawannya, dapat mendorong karyawan untuk berperilaku kreatif, inovatif dan mampu memecahkan masalah dengan pendekatan baru. Selain itu, pemimpin transformasional juga seharusnya peduli pada permasalahan yang dihadapi karyawan serta selalu memberikan motivasi agar dapat meningkatkan kinerja sehingga akan tercipta kepuasan kerja bagi para karyawannya. Jika pemimpinin tidak bisa memberikan keteladanan sebagai panutan bagi karyawannya, masalah ini memungkinkan terjadinya ketidakpuasan kerja dari karyawan dan bisa mengakibatkan tujuan perusahaan tidak dapat terpenuhi secara optimal.

Budaya organisasi PT Pos Indonesia (Persero) terdiri atas unsur nilai-nilai dasar yang dapat dilihat (observable) dan yang tidak kelihatan (unobservable). Pada level observable, budaya organisasi mencakup beberapa aspek organisasi seperti arsitektur, logo perusahaan, peraturan, pola perilaku, bahasa, dan cara berpakaian, sedangkan pada level unobservable, budaya organisasi mencakup norma-norma, keyakinan/kepercayaan, asumsi-asumsi para anggota organisasi untuk mengelola masalah, dan keadaan-keadaan di sekitarnya. Untuk menerapkan suatu budaya organisasi bukanlah suatu pekerjaan yang mudah karena pada dasarnya karyawan PT Pos Indonesia (Persero) mempunyai karakteristik tingkah laku yang berbeda sesuai dengan tingkat kebutuhannya.

Adapun budaya organisasi PT Pos Indonesia (Persero) adalah : (1) berusaha mencapai yang terbaik, (2) bertanggung jawab kepada pihak yang berkepentingan, (3) senantiasa melihat ke depan dan belajar dari pengalaman, (4), ikatan yang lestari di antara seluruh jajaran, baik karyawan yang baru, yang sedang menjabat 
maupun sudah pensiun, terjalin baik di luar atau di dalam lingkungan kerja, dan (5) bangga sebagai insan PT Pos Indonesia (Persero).

Masalah yang umumnya terjadi pada PT Pos Indonesia Denpasar berkaitan dengan budaya organisasi adalah adanya perbedaan seperti kesenjangan persepsi karyawan dengan persepsi pimpinan mengenai budaya organisasi yang dirasakan dan yang diharapkan, sehingga tercipta ketidakharmonisan kerja. Hal ini memungkinkan terjadinya ketidakpuasan kerja dari karyawan sehingga dapat menimbulkan penurunan kerja yang akhirnya mengakibatkan tujuan perusahaan tidak dapat terpenuhi secara optimal.

PT Pos Indonesia (Persero) Denpasar juga memperhatikan pentingnya pelaksanaan program keselamatan dan kesehatan kerja. Perhatian perusahaan tentang K3 dapat membuat karyawan merasa senang serta memiliki kepuasan dalam bekerja yang berakibat karyawan dapat terhindar dari resiko kecelakaan kerja.

Beberapa keluhan karyawan terjadi berkaitan dengan program keselamatan dan kesehatan kerja di PT Pos Indonesia Denpasar. Kurang memadainya alat-alat pengamanan yang disediakan oleh perusahaan untuk melindungi karyawan jika terjadi kecelakaan kerja seperti alat pemadam kebakaran dan kamera (CCTV) yang tidak berfungsi baik sehingga kurang menjamin keselamatan karyawan. Kondisi beberapa peralatan dan fasilitas teknik yang kurang aman, seperti pipa air yang bocor, kabel yang rusak dan penempatannya yang tidak teratur sehingga dapat membahayakan karyawan. Ruang kerja karyawan khususnya pada bagian produksi tidak mempunyai ruang gerak yang memadai dalam melakukan aktivitas kerja, hal ini dapat dilihat dari kurang luasnya ruang kerja jika dibandingkan dengan peralatan yang ada. Tidak diberikan pemeriksaan kesehatan awal dan berkala bagi setiap karyawan padahal sudah merupakan aturan setiap perusahaan harus menyediakan itu. Hal ini menyebabkan karyawan tidak dapat menyelesaikan pekerjaannya dengan baik jika terganggu kesehatannya. Ruang kesehatan yang kurang memadai, sehingga jika karyawan mengalami gangguan kesehatan pada saat kerja maka karyawan dibantu rekannya akan berobat ke klinik atau rumah sakit untuk memeriksa masalah kesehatannya.

Adanya perhatian dan ditemui permasalahan berkaitan dengan gaya kepemimpinan transformasional, budaya organisasi, program keselamatan dan kesehatan kerja dalam usaha meningkatkan kepuasan kerja karyawan maka sangat layak dalam penelitian ini diteliti lebih jauh lagi pengaruh gaya kepemimpinan, budaya organisasi, program keselamatan dan kesehatan kerja terhadap kepuasan kerja karyawan di PT Pos Indonesia Denpasar.

Kepemimpinan transformasional pada prinsipnya dapat memotivasi bawahan untuk berbuat lebih baik dari pada yang biasa dilakukan. Kepemimpinan transformasional ini sangat kuat pengaruhnya terhadap munculnya kepuasan kerja karyawan terutama karena karakteristik pemimpin yang peduli pada keberbedaan kemampuan karyawan (Rorimpandey, 2013). Gaya kepemimpinan transformasional bisa membawa perubahan signifikan yang membawa pengaruh terhadap kepuasan kerja karyawan (Thamrin, 2012).

Gupta (2012) dalam penelitiannya menemukan bahwa kepuasan kerja karyawan dipengaruhi oleh variabel gaya kepemimpinan transformasional. 
Purnomo \& Muhammad (2010) menemukan bahwa gaya kepemimpinan transformasional berpengaruh positif dan signifikan terhadap kepuasan kerja. Saputra (2012) dalam penelitiannya menyatakan bahwa terdapat pengaruh langsung dan signifikan antara gaya kepemimpinan transformasional terhadap kepuasan kerja karyawan. Wijanto (2013) menemukan bahwa variabel gaya kepemimpinan mempunyai pengaruh yang positif dan paling dominan terhadap kepuasan kerja karyawan.

Hasil penelitian serupa yang dilakukan oleh Amaliyah dkk, (2014) serta Supartha (2010) juga menyatakan bahwa kepemimpinan transformasional berpengaruh positif dan signifikan terhadap kepuasan kerja. Hal ini menunjukkan bahwa semakin baik penerapan kepemimpinan transformasional maka akan meningkatkan kepuasan kerja karyawan. Berdasarkan telaah landasan teori yang ada, maka dapat disusun hipotesis sebagai berikut.

$\mathrm{H}_{1}$ : Gaya kepemimpinan transformasional berpengaruh positif terhadap kepuasan kerja karyawan

Karakteristik dari budaya organisasi akan menentukan budaya organisasi yang kuat atau rendah, kekuatan budaya organisasi akhirnya akan menentukan tingkat kepuasan dan kinerja dari karyawan. Pembentukan budaya organisasi yang kuat membutuhkan suatu proses karena perubahan yang terjadi dalam organisasi menyangkut perubahan orang-orang yang berada dalam organisasi termasuk di dalamnya perbedaan persepsi, keinginan, sikap, dan perilaku. Kesesuaian antara karakteristik organisasi dengan keinginan karyawan harus dicapai yang mengarah pada tingkat kebersamaan yang tinggi. Dalam menyiapkan perubahan, karyawan diharapkan merasa aman dan bahagia dalam melakukan pekerjaannya. Sehingga dengan demikian, karyawan akan bersedia menerima perubahan dengan tulus tanpa ada rasa takut atau terpaksa. Sejalan dengan hal tersebut, dapat dipahami bahwa budaya organisasi memiliki peran yang amat penting dalam meningkatkan kepuasan kerja dan kinerja organisasi. Hal tersebut sesuai dengan studi Mehr (2012) yang menemukan hasil bahwa adanya hubungan yang signifikan antara budaya organisasi dengan kepuasan kerja, jika karyawan menunjukkan tingkat yang lebih tinggi untuk identitas budaya organisasi, maka tingkat kepuasan kerja juga akan lebih tinggi.

Pernyataan ini dipertegas dengan kajian empirik penelitian Nafrizal (2012) yang menemukan bahwa budaya organisasi berpengaruh positif dan signifikan terhadap kepuasan kerja. Penelitian Purnama (2013) menunjukkan bahwa budaya organisasi yang kuat memberikan efek positif bagi peningkatan kepuasan kerja karyawan. Bigliardi \& Alberto (2012) menemukan bahwa budaya organisasi berpengaruh terhadap kepuasa kerja pada pengetahuan karyawan. Penelitian (Kurniawati \& Sariyathi, 2015) menemukan bahwa berdasarkan hasil analisis data dari penelitian yang telah dilakukan dapat diketahui terdapat pengaruh yang signifikan dari budaya organisasi terhadap kepuasan kerja karyawan.

Penelitian serupa oleh Rizondra (2013) juga memperoleh hasil bahwa terdapat pengaruh signifikan positif antara budaya organisasi dengan kepuasan kerja, yakni jika semakin tinggi budaya organisasi yang ada pada pegawai maka akan semakin tinggi tingkat kepuasan kerja yang dirasakan oleh pegawai, sebaliknya jika budaya organisasi pegawai rendah dalam bekerja maka semakin 
turun juga kepuasan yang akan dimiliki dalam bekerja. Berdasarkan telaah landasan teori yang ada, maka dapat disusun hipotesis sebagai berikut:

$\mathrm{H}_{2}$ : Budaya organisasi berpengaruh positif terhadap kepuasan kerja karyawan

Keselamatan dan kesehatan kerja saat ini menjadi kewajiban dan kebutuhan perusahaan dalam segala bentuk kegiatan pekerjaan. Keselamatan dan kesehatan kerja merupakan salah satu bentuk upaya untuk menciptakan tempat kerja yang aman, sehat, bebas dari pencemaran lingkungan, sehingga dapat melindungi karyawannya dari kecelakaan kerja. Apabila program keselamatan dan kesehatan kerja telah dilaksanakan secara optimal maka hal itu dapat menghasilkan kepuasan kerja karyawan (Amaliyah et al., 2014).

Pernyataan ini dipertegas dengan hasil penelitian terdahulu oleh Kurniawan (2011) yang menemukan bahwa program keselamatan dan kesehatan kerja berpengaruh positif terhadap kepuasan kerja karyawan. Rahim (2012) menemukan bahwa berdasarkan hasil analisis yang telah dilakukan diketahui kesehatan kerja dan keselamatan kerja memiliki pengaruh yang signifikan terhadap kepuasan kerja karyawan. Estiawan (2012) dalam penelitiannya menemukan bahwa variabel dari Sistem Manajemen Keselamatan dan Kesehatan Kerja (SMK3) yang terdiri dari variabel komitmen dan kebijakan manajemen terhadap $\mathrm{K} 3$, perencanaan $\mathrm{K} 3$, implementasi $\mathrm{K} 3$, pemeriksaan $\mathrm{K} 3$, dan tinjauan manajemen dan peningkatan SMK3 secara simultan bersama-sama mempunyai pengaruh signifikan terhadap kepuasan kerja karyawan. Hasil penelitian Yusnita (2012) menemukan ada pengaruh yang signifikan antara program K3 terhadap kepuasan kerja karyawan.

Hasil penelitian serupa oleh Sageer (2012) juga menemukan bahwa program keselamatan dan kesehatan kerja berpengaruh positif dan signifikan terhadap kepuasan kerja karyawan. Hal ini menunjukkan bahwa program keselamatan dan kesehatan kerja yang meningkat dapat meningkatkan kepuasan kerja karyawan. Berdasarkan telaah landasan teori yang ada, maka dapat disusun hipotesis sebagai berikut:

$\mathrm{H}_{3}$ : Program keselamatan dan kesehatan kerja berpengaruh positif terhadap kepuasan kerja karyawan

\section{METODE PENELITIAN}

Penelitian ini bersifat asosiatif yang bertujuan untuk menganalisis hubungan gaya kepemimpinan transformasional, budaya organisasi, program keselamatan dan kesehatan kerja terhadap kepuasan kerja karyawan. Penelitian ini dilakukan pada PT Pos Indonesia Denpasar, yang beralamat di Jalan Raya Puputan Renon, Denpasar. Adapun yang melatarbelakangi pemilihan lokasi pada penelitian ini karena ditemukan masalah berkaitan dengan gaya kepemimpinan transformasional, budaya organisasi, program keselamatan dan kesehatan kerja dalam usaha meningkatkan kepuasan kerja karyawan di PT Pos Indonesia Denpasar. Sedangkan obyek dalam penelitian adalah bidang manajemen sumber daya manusia yaitu kepuasan kerja karyawan, gaya kepemimpinan transformasional, budaya organisasi, program keselamatan dan kesehatan kerja. 
Berdasarkan penelusuran teori dan pembahasan hasil penelitian sebelumnya, maka kerangka konseptual dapat digambarkan sebagai berikut pada Gambar 1 berikut.

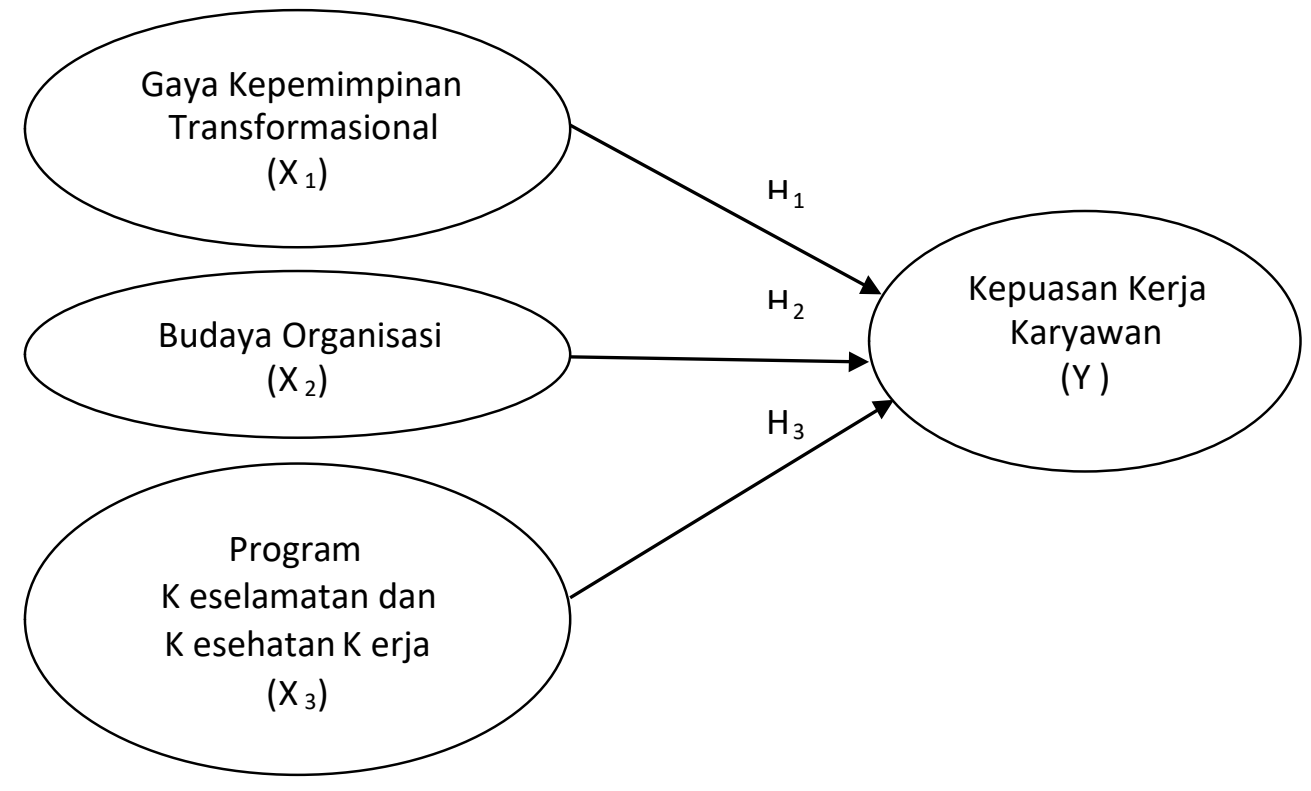

\section{Gambar 1. Kerangka Konseptual}

Variabel bebas dalam penelitian ini adalah gaya kepemimpinan transformasional $\left(\mathrm{X}_{1}\right)$, budaya organisasi $\left(\mathrm{X}_{2}\right)$, program keselamatan dan kesehatan kerja $\left(\mathrm{X}_{3}\right)$. Sedangkan variabel terikat dalam penelitian ini adalah kepuasan kerja karyawan (Y).

Jenis data yang digunakan dalam penelitian ini adalah data kuantitatif berupa jumlah karyawan, skor jawaban kuesioner kepuasan kerja karyawan, gaya kepemimpinan transformasional, budaya organisasi, program keselamatan dan kesehatan kerja. Data kualitatif berupa sejarah perusahaan, struktur organisasi dan deskripsi jabatan. Sedangkan data primer dalam penelitian ini yaitu pernyataan karyawan sebagai responden dalam pengisian kuesioner kepuasan kerja karyawan, gaya kepemimpinan transformasional, budaya organisasi, program keselamatan dan kesehatan kerja. Data sekunder berupa data yang diperoleh dari dokumendokumen dari PT Pos Indonesia Denpasar.

Populasi dalam penelitian ini adalah karyawan PT Pos Indonesia Denpasar tahun 2016 sebanyak 305 orang, tidak termasuk Top Management yaitu 1 orang Kepala Kantor dan 1 orang Manajer Operasional, serta 3 orang bagian audit. Metode pengambilan sampel dalam penelitian ini menggunakan proportionate stratified random sampling sehingga didapat jumlah sampel penelitian sebagai responden adalah sebanyak 80 orang karyawan PT Pos Indonesia Denpasar.

Metode pengumpulan data yang digunakan dalam penelitian ini adalah kuesioner yaitu dengan menyebarkan daftar pernyataan secara tertulis, agar responden menjawab sendiri pernyataan-pernyataan tersebut yang berkaitan dengan objek penelitian. Wawancara yaitu tanya jawab dengan pihak terkait dalam perusahaan yaitu dengan pimpinan atau staff perusahaan yang berkaitan 
dengan objek penelitian. Observasi yaitu mengadakan pengamatan langsung pada objek penelitian dan melakukan pencatatan terkait dengan masalah yang diteliti.

Hasil tabulasi jawaban responden selanjutnya dianalisis dengan menggunakan analisis faktor dengan bantuan program SPSS 20.0 for Windows. Sedangkan teknik analisis regresi linear berganda digunakan untuk mengetahui pengaruh gaya kepemimpinan transformasional, budaya organisasi, program keselamatan dan kesehatan kerja terhadap kepuasan kerja karyawan. Hasil analisis dinyatakan dalam bentuk persamaan regresi linier berganda.

$\hat{Y}=a+b_{1} X_{1}+b_{2} X_{2}+b_{3} X_{3}+e i$

Keterangan:

$\mathrm{Y}=$ Kepuasan kerja karyawan

$\alpha=$ Konstanta

$\beta_{1}=$ Koefisien regresi gaya kepemimpinan transformasional

$\beta_{2}=$ Koefisien regresi budaya organisasi

$\beta_{3}=$ Koefisien regresi program keselamatan dan kesehatan kerja

$\mathrm{X}_{1}=$ Gaya kepemimpinan transformasional

$\mathrm{X}_{2}=$ Budaya organisasi

$\mathrm{X}_{3}=$ Program keselamatan dan kesehatan kerja

$\mathrm{e}=$ Errorterm

Sebelum digunakan untuk uji simultan dan parsial, harus memenuhi syarat uji asumsi klasik. Pengujian asumsi klasik dalam penelitian ini meliputi uji normalitas, uji multikolinearitas dan uji heteroskedastisitas.

\section{HASIL DAN PEMBAHASAN}

Karakteristik responden meliputi jenis kelamin, usia, dan pendidikan terakhir responden. Ringkasan mengenai karakteristik responden dapat dilihat pada Tabel 1.

Tabel 1. menunjukkan bahwa jumlah laki-laki sebanyak 60 orang dengan persentase 75 persen dan jumlah perempuan sebanyak 20 orang dengan persentase sebesar 25 persen. Hal tersebut menunjukkan bahwa karyawan yang bekerja di PT Pos Indonesia Denpasar dominan laki-laki dibandingan dengan perempuan. Berdasarkan usia menunjukkan bahwa responden yang berusia antara 18-23 tahun adalah sebanyak 28 orang (35 persen). Responden yang berusia antara 24-29 tahun adalah sebanyak 35 orang (43,75 persen). Responden yang berusia antara 30-35 tahun adalah sebanyak 10 orang $(11,25$ persen). Responden yang berusia di atas sama dengan 36 tahun adalah sebanyak 9 orang (11,25 persen). Hal ini menunjukkan bahwa karyawan yang bekerja Di PT Pos Indonesia Denpasar lebih di dominasi usia 24-29 Tahun. Berdasarkan pendidikan menunjukkan bahwa responden yang memiliki pendidikan SMA adalah sebanyak 22 orang $(27,50$ persen). Responden yang memiliki pendidikan Diploma adalah sebanyak 53 orang (66,25persen). Responden yang memiliki pendidikan Sarjana adalah sebanyak 15 orang (18,75 persen). Hal ini menunjukkan bahwa tingkat pendidikan karyawan di PT Pos Indonesia Denpasar yang dominan adalah Diploma. 
Tabel 1.

Karakteristik Responden

\begin{tabular}{ccccc}
\hline No & Variabel & Klasifikasi & Jumlah & Persentase (\%) \\
\hline 1 & Jenis Kelamin & Laki-laki & 60 & 75 \\
& & Perempuan & 20 & 25 \\
2 & Jumlah & $18-23$ & $\mathbf{8 0}$ & $\mathbf{1 0 0}$ \\
& Usia & $24-29$ & 35 & 43.75 \\
& & $30-35$ & 8 & 10 \\
& & 236 & 9 & 11,25 \\
3 & & & $\mathbf{8 0}$ & $\mathbf{1 0 0}$ \\
& Jumlah & SMA & 22 & 27,50 \\
& & Diploma & 53 & 66.25 \\
& & Sarjana & 15 & 18.75 \\
& & $\mathbf{8 0}$ & $\mathbf{1 0 0}$ \\
\hline
\end{tabular}

Sumber: Data primer diolah, 2018

Pengujian reliabilitas tiap butir pertanyaan atau pernyataan dalam instrumen penelitian ini menggunakan metode Cronbach's Alpha. Instrumen dikatakan reliabel untuk mengukur variabel bila berada di atas angka 0,60. Hasil pengujian reliabilitas instrumen dapat dilihat pada Tabel 2.

Tabel 2.

Hasil Uji Reliabilitas

\begin{tabular}{clcc}
\hline No & Variabel & Cronbach'sAlpha & Keterangan \\
\hline 1 & Gaya kepemimpinan transformasional $\left(\mathrm{X}_{1}\right)$ & 0,907 & Reliabel \\
2 & Budaya organisasi $\left(\mathrm{X}_{2}\right)$ & 0,932 & Reliabel \\
3 & Program keselamatan dan kesehatan kerja $\left(\mathrm{X}_{3}\right)$ & 0,918 & Reliabel \\
4 & Kepuasan kerja $(\mathrm{Y})$ & 0,950 & Reliabel \\
\hline
\end{tabular}

Sumber: Data primer diolah, 2018

Berdasarkan Tabel 2. ditunjukkan bahwa keempat instrumen penelitian yaitu variabel Gaya kepemimpinan transformasional, budaya organisasi, program keselamatan dan kesehatan kerja dan kepuasan kerja memiliki koefisien Cronbach's Alpha lebih besar dari 0,60 sehingga seluruh pernyataan tersebut memenuhi syarat reliabilitas instrumen dan dapat dinyatakan reliabel.

Suatu instrumen dikatakan valid apabila memiliki koefisien korelasi antara butir dengan skor total dalam instrumen tersebut lebih besar dari 0,30 dengan tingkat kesalahan Alpha 0,05. Tabel 3.

Berdasarkan hasil uji validitas pada Tabel 3. di atas menunjukkan bahwa seluruh pernyataan pada variabel Gaya kepemimpinan transformasional, budaya organisasi, program keselamatan dan kesehatan kerja dan kepuasan kerja memiliki nilai koefisien korelasi dengan skor total seluruh item pernyataan lebih besar dari 0,30 , sehingga seluruh indikator tersebut telah memenuhi syarat validitas data dan dapat dinyatakan valid.

Uji Kaiser Meyer Olkin digunakan untuk mengetahui kecukupan sampel. Analisis faktor dianggap layak jika besaran KMO memiliki nilai minimal 0,5. Hasil uji menunjukkan semua variabel memiliki $\mathrm{KMO}>0,5$. Hal ini 
menyimpulkan bahwa masing-masing variabel memiliki kecukupan sampel untuk analisis faktor.

Kelayakan model uji faktor untuk masing-masing variabel dapat dilihat dari nilai Measures of Sampling Adequancy (MSA). Hasil analisis menunjukkan bahwa nilai MSA masing-masing variabel lebih besar dari 0,5. Hal ini berarti masing-masing model layak digunakan dalam analisis faktor.

Tabel 3.

Hasil Uji Validitas

\begin{tabular}{|c|c|c|c|c|}
\hline No & Variabel & Item Pernyataan & Korelasi Item Total & Keterangan \\
\hline \multirow{4}{*}{1} & \multirow{4}{*}{$\begin{array}{l}\text { Gaya kepemimpinan } \\
\text { transformasional }\left(\mathrm{X}_{1}\right)\end{array}$} & $\mathrm{X}_{1.1}$ & 0,886 & Valid \\
\hline & & $\mathrm{X}_{1.2}$ & 0,762 & Valid \\
\hline & & $\mathrm{X}_{1.3}$ & 0,936 & Valid \\
\hline & & $\mathrm{X}_{1.4}$ & 0,944 & Valid \\
\hline \multirow{3}{*}{2} & \multirow{3}{*}{ Budaya organisasi $\left(\mathrm{X}_{2}\right)$} & $\mathrm{X}_{2.1}$ & 0,863 & Valid \\
\hline & & $\mathrm{X} 2.2$ & 0,900 & Valid \\
\hline & & $\mathrm{X} 2.3$ & 0,932 & Valid \\
\hline \multirow{7}{*}{3} & \multirow{7}{*}{$\begin{array}{l}\text { Program keselamatan dan } \\
\text { kesehatan kerja }\left(X_{3}\right)\end{array}$} & $\mathrm{X}_{2.4}$ & 0,936 & Valid \\
\hline & & $\mathrm{X}_{2.5}$ & 0,794 & Valid \\
\hline & & $\mathrm{X}_{3.1}$ & 0,591 & Valid \\
\hline & & $\mathrm{X}_{3.2}$ & 0,940 & Valid \\
\hline & & $\mathrm{X}_{3.3}$ & 0,941 & Valid \\
\hline & & $\mathrm{X}_{3.4}$ & 0,937 & Valid \\
\hline & & $\mathrm{X}_{3.5}$ & 0,915 & Valid \\
\hline \multirow{8}{*}{4} & \multirow{8}{*}{ Kepuasan kerja (Y) } & Y1.1 & 0,890 & Valid \\
\hline & & Y1.2 & 0,879 & Valid \\
\hline & & Y1.3 & 0,876 & Valid \\
\hline & & $\mathrm{Y}_{1.4}$ & 0,840 & Valid \\
\hline & & $\mathrm{Y}_{1.5}$ & 0,688 & Valid \\
\hline & & $\mathrm{Y}_{1.6}$ & 0,902 & Valid \\
\hline & & $\mathrm{Y}_{1.7}$ & 0,915 & Valid \\
\hline & & $\mathrm{Y}_{1.8}$ & 0,899 & Valid \\
\hline
\end{tabular}

Sumber: Data primer diolah, 2018

Nilai Persentage of Variance masing-masing variabel lebih besar dari 60 persen. Hal ini berarti faktor dari masing-masing variabel memiliki kelayakan untuk menjelaskan variabel faktornya.

Berdasarkan Tabel 4. dapat diketahui bahwa nilai Asymp. Sig. (2-tailed) sebesar 0,476 dan lebih besar dari $\alpha=0,05$. Jadi, dapat disimpulkan bahwa data tersebut telah memenuhi syarat normalitas dan data tersebut dikatakan berdistribusi normal. 
Tabel 4.

Hasil Uji Normalitas

\begin{tabular}{llr}
\hline & & Unstandardized Residual \\
\hline $\mathrm{N}$ & & 80 \\
Normal Parameters ${ }^{\mathrm{a}, \mathrm{b}}$ & Mean & .0000000 \\
& Std. Deviation & .23336888 \\
Most Extreme Differences & Absolute & .094 \\
& Positive & .059 \\
& Negative & -.094 \\
Kolmogorov-Smirnov Z & & .843 \\
Asymp. Sig. (2-tailed) & & .476 \\
\hline Sumber: Hasil pengolahan data primer, 2018 & &
\end{tabular}

Tabel 5.

Hasil Uji Multikoleniaritas

\begin{tabular}{|c|c|c|}
\hline \multirow{2}{*}{ Variabel } & \multicolumn{2}{|c|}{ Collinearity Statistics } \\
\hline & Tolerance & VIF \\
\hline Gaya kepemimpinan transformasional & 0.341 & 2.935 \\
\hline Budaya organisasi & 0.457 & 2.187 \\
\hline Program keselamatan dan kesehatan kerja & 0.429 & 2.332 \\
\hline
\end{tabular}

Sumber: Hasil pengolahan data primer, 2018

Hasil pengujian tolerance menunjukan seluruh variabel bebas memiliki nilai tolerance lebih besar dari 0,10 (10\%). Hasil perhitungan VIF juga menunjukan bahwa seluruh variabel bebas memiliki nilai VIF kurang dari 10. Oleh karena itu, maka dapat disimpulkan bahwa tidak terjadi multikolinearitas antar variabel independen dalam model regresi tersebut.

Hasil pengujian menunjukkan bahwa signifikansinya lebih dari $\alpha=0,05$ terhadap absolut residual (abs_Res) secara parsial. Berdasarkan hal tersebut, maka dapat disimpulkan bahwa dalam model regresi tersebut tidak terdapat heteroskedastisitas.

Tabel 6.

Hasil Uji Heteroskedastisitas

\begin{tabular}{lcc}
\hline \multicolumn{1}{c}{ Variabel } & T & Signifikansi \\
\hline Gaya kepemimpinan transformasional & 0.351 & 0.727 \\
Budaya organisasi & 1.188 & 0.238 \\
program keselamatan dan kesehatan kerja & -0.819 & 0.415 \\
\hline
\end{tabular}

Sumber: Hasil pengolahan data primer, 2018

Perhitungan koefisien regresi linier berganda dilakukan dengan analisis regresi, diperoleh hasil yang ditunjukan pada Tabel 7.

Berdasarkan Tabel 7. persamaan regresi linear berganda sebagai berikut:

$\mathrm{Y}=0,000+0,698 \mathrm{X}_{1}+0,149 \mathrm{X}_{2}+0,200 \mathrm{X}_{3}$

Nilai konstanta $(\alpha)$ sebesar 0,000 berarti apabila gaya kepemimpinan transformasional $\left(\mathrm{X}_{1}\right)$, budaya organisasi $\left(\mathrm{X}_{2}\right)$, dan program keselamatan dan kesehatan kerja $\left(\mathrm{X}_{3}\right)$ konstan atau bernilai 0 , maka kepuasan kerja karyawan adalah sebesar 0,000 satuan. 
Nilai adjusted $\mathrm{R}^{2}$ adalah sebesar 0,946 yang berarti bahwa sebesar 94,6 persen kepuasan kerja Karyawan PT Pos Indonesia Denpasar dipengaruhi oleh gaya kepemimpinan transformasional, budaya organisasi, dan program keselamatan dan kesehatan kerja sedangkan sisanya sebesar 5,4 persen dipengaruhi oleh variabel lainnya di luar model penelitian.

Tabel 7.

Hasil Analisis Regresi Linear Berganda

\begin{tabular}{|c|c|c|c|c|c|}
\hline \multirow{2}{*}{\multicolumn{2}{|c|}{ Variabel }} & \multicolumn{2}{|c|}{ Koefisien Regresi } & \multirow{2}{*}{$\mathbf{t}$} & \multirow{2}{*}{ Sig } \\
\hline & & $\mathbf{B}$ & Std. error & & \\
\hline Gaya kepe & transformasional & 0,698 & 0.046 & 15.225 & 0.000 \\
\hline \multicolumn{2}{|c|}{ Budaya organisasi } & 0,149 & 0.040 & 3.774 & 0.000 \\
\hline \multicolumn{2}{|c|}{ Program keselamatan dan kesehatan kerja } & 0,200 & 0.041 & 4.885 & 0.000 \\
\hline (Constant) & $: 0,000$ & & & & \\
\hline F Statistik & : 439,831 & & & & \\
\hline Sig F & 0,000 & & & & \\
\hline $\mathrm{R}^{2}$ & 0,946 & & & & \\
\hline
\end{tabular}

Sumber: Hasil pengolahan data primer, 2018

Hasil Uji Anova atau ( $F$ test) menunjukkan nilai $\mathrm{F}$ hitung sebesar 439,831, dengan signifikansi 0,000 yang probabilitas signifikansi lebih kecil dari alpha 0,05 . Ini menunjukkan bahwa gaya kepemimpinan transformasional, budaya organisasi dan program keselamatan dan kesehatan kerja dapat digunakan untuk memprediksi kepuasan kerja Karyawan PT Pos Indonesia Denpasar atau dapat dikatakan bahwa gaya kepemimpinan transformasional, budaya organisasi dan program keselamatan dan kesehatan kerja secara bersama-sama berpengaruh terhadap kepuasan kerja Karyawan PT Pos Indonesia Denpasar.

Uji parsial (uji t) digunakan untuk menguji pengaruh masing-masing variabel bebas terhadap variabel terikat.

Hasil analisis menunjukkan bahwa nilai sig $=0,000<0,05$ artinya gaya kepemimpinan transformasional berpengaruh positif signifikan terhadap kepuasan kerja karyawan PT Pos Indonesia Denpasar. Hasil penelitian ini mendukung hasil penelitian Rorimpandey (2013) yang menyatakan bahwa terdapat pengaruh yang positif dan signifikan antara gaya kepemimpinan terhadap kepuasan kerja karyawan. Hal ini disebabkan karena kepemimpinan transformasional pada prinsipnya dapat memotivasi bawahan untuk berbuat lebih baik dari pada yang biasa dilakukan. Kepemimpinan transformasional ini sangat kuat pengaruhnya terhadap munculnya kepuasan kerja karyawan terutama karena karakteristik pemimpin yang peduli pada keberbedaan kemampuan karyawan.

Hasil penelitian ini juga didukung oleh penelitian yang dilakukan oleh Amaliyah et al. (2014) serta Supartha (2010) juga menyatakan bahwa kepemimpinan transformasional berpengaruh positif dan signifikan terhadap kepuasan kerja. Hal ini menunjukkan bahwa semakin baik penerapan kepemimpinan transformasional maka akan meningkatkan kepuasan kerja karyawan.

Hasil analisis menunjukkan bahwa nilai sig $=0,000<0,05$ artinya budaya organisasi berpengaruh positif signifikan terhadap kepuasan kerja karyawan PT 
Pos Indonesia Denpasar. Hasil penelitian ini mendukung penelitian Nafrizal (2012) yang menemukan bahwa budaya organisasi berpengaruh positif dan signifikan terhadap kepuasan kerja. Hal ini menunjukkan bahwa karakteristik dari budaya organisasi akan menentukan budaya organisasi yang kuat atau rendah, kekuatan budaya organisasi akhirnya akan menentukan tingkat kepuasan dan kinerja dari karyawan.

Pembentukan budaya organisasi yang kuat membutuhkan suatu proses karena perubahan yang terjadi dalam organisasi menyangkut perubahan orangorang yang berada dalam organisasi termasuk di dalamnya perbedaan persepsi, keinginan, sikap, dan perilaku. Kesesuaian antara karakteristik organisasi dengan keinginan karyawan harus dicapai yang mengarah pada tingkat kebersamaan yang tinggi. Dalam menyiapkan perubahan, karyawan diharapkan merasa aman dan bahagia dalam melakukan pekerjaannya. Sehingga dengan demikian, karyawan akan bersedia menerima perubahan dengan tulus tanpa ada rasa takut atau terpaksa. Sejalan dengan hal tersebut, dapat dipahami bahwa budaya organisasi memiliki peran yang amat penting dalam meningkatkan kepuasan kerja dan kinerja organisasi.

Hasil penelitian ini juga mendukung temuan penelitian serupa oleh Rizondra (2013) dan Hermawan (2015) yang memperoleh hasil bahwa terdapat pengaruh signifikan positif antara budaya organisasi dengan kepuasan kerja, yakni jika semakin tinggi budaya organisasi yang ada pada pegawai maka akan semakin tinggi tingkat kepuasan kerja yang dirasakan oleh pegawai, sebaliknya jika budaya organisasi pegawai rendah dalam bekerja maka semakin turun juga kepuasan yang akan dimiliki dalam bekerja.

Hasil analisis menunjukkan bahwa nilai sig $=0,000<0,05$ artinya program keselamatan dan kesehatan kerja berpengaruh positif signifikan terhadap kepuasan kerja karyawan PT Pos Indonesia Denpasar. Hasil penelitian ini sesuai dengan temuan penelitian Kurniawan (2011), Estiawan (2012) yang menemukan bahwa program keselamatan dan kesehatan kerja berpengaruh positif terhadap kepuasan kerja karyawan. Keselamatan dan kesehatan kerja merupakan salah satu bentuk upaya untuk menciptakan tempat kerja yang aman, sehat, bebas dari pencemaran lingkungan, sehingga dapat melindungi karyawannya dari kecelakaan kerja. Apabila program keselamatan dan kesehatan kerja telah dilaksanakan secara optimal maka hal itu dapat menghasilkan kepuasan kerja karyawan (Amaliyah et al., 2014).

Hasil penelitian ini juga mendukung temuan penelitian Yusnita (2012), dan Sageer (2012) yang menemukan bahwa program keselamatan dan kesehatan kerja berpengaruh positif dan signifikan terhadap kepuasan kerja karyawan. Hal ini menunjukkan bahwa program keselamatan dan kesehatan kerja yang meningkat dapat meningkatkan kepuasan kerja karyawan.

\section{SIMPULAN}

Berdasarkan hasil pembahasan penelitian yang telah dilakukan, maka dapat disimpulkan bahwa Gaya kepemimpinan transformasional berpengaruh positif dan signifikan terhadap kepuasan kerja karyawan PT Pos Indonesia Denpasar. Hal 
tersebut berarti semakin baik penerapan gaya kepemimpinan transformasional pada PT Pos Indonesia Denpasar, maka akan dapat membentuk kepuasan kerja karyawan yang semakin meningkat. Budaya organisasi berpengaruh positif dan signifikan terhadap kepuasan kerja karyawan PT Pos Indonesia Denpasar. Hal tersebut berarti semakin kuat penerapan budaya organisasi pada PT Pos Indonesia Denpasar maka akan dapat membentuk kepuasan kerja karyawan PT Pos Indonesia Denpasar yang semakin meningkat. Program keselamatan dan kesehatan kerja berpengaruh positif dan signifikan terhadap kepuasan kerja karyawan PT Pos Indonesia Denpasar. Hal tersebut berarti semakin baik pelaksanaan program keselamatan dan kesehatan kerja maka akan dapat membentuk kepuasan kerja karyawan PT Pos Indonesia Denpasar yang semakin meningkat.

Berdasarkan kesimpulan dan pembahasan hasil penelitian, maka saran-saran yang dapat diberikan adalah sebagai berikut: (1) Pemimpin PT Pos Indonesia Denpasar disarankan mampu mendorong karyawan dan memberikan semangat dalam bekerja dengan memberikan motivasi yang dapat meningkatkan semangat kerja karyawan. (2) Sebaiknya PT Pos Indonesia Denpasar selalu menghargai pengabdian yang dilakukan oleh karyawan agar mereka merasa senang, seandainya perusahaan tidak menghargai pengabdian karyawan, maka hal tersebut dapat menurunkan tingkat kepuasan kerja Karyawan PT Pos Indonesia Denpasar. (3) Sebaiknya PT Pos Indonesia Denpasar selalu memperhatikan kelegaan ruang kerja karyawan, dan memilah limbah yang dihasilkan sehingga karyawan merasa nyaman dalam bekerja, sehingga kedepannya dapat meningkatkan kepuasan kerja karyawan. (4) Peneliti selanjutnya disarankan untuk menambahkan variabel lain seperti kompensasi, stress kerja , yang dapat mempengaruhi tingkat kepuasan kerja karyawan. Peneliti selanjutnya juga disarankan memperluas cakupan wilayah penelitian sehingga penelitian dapat digeneralisasikan.

\section{REFERENSI}

Amaliyah, F., Swasto, B., dan Susilo, H. (2014). Pengaruh Gaya Kepemimpinan Transformasional Terhadap Kepuasan Kerja Karyawan Dengan Motivasi Kerja Karyawan Sebagai variable Mediasi. Jurnal Administrasi Bisnis, 14(1).

Abadiyah, R., dan Purwanto, D. (2016). Pengaruh Budaya Organisasi, Kompensasi Terhadap Kepuasan Kerja Dan Kinerja Pegawai Bank di Surabaya. Jurnal Bisnis, Manajemen \& Perbankan, 2(1), 49-66.

Anggrini. (2013). Keselamatan dan Kesehatan Kerja Terhadap Kepuasan Kerja Karyawan Pengaruh. Jurnal Administrasi Bisnis, 1(1). 
Ardana, I. K., dan Mujiati, W. (2012). Manajemen Sumber Daya Manusia. Denpasar: UPT Penerbit Universitas Udayana.

Aria. (2015). Pengaruh Keselamatan dan Kesehatan Kerja Terhadap Kepuasan Kerja Karyawan (Studi pada Karyawan bagian Produksi PT Hankook Tire Indonesia, Cikarang). Jurnal Administrasi Bisnis, 29(1).

Bigliardi, B., and Alberto. (2012). The impact of organizational culture on the job satisfaction of knowledge workers. Italy: University of Parma.

Charles, W. I., and Kustini. (2016). Pengaruh keselamatan dan Kesehatan Kerja Terhadap Kepuasan Kerja dan Dampaknya terhadap Komitmen Karyawan. Jurnal mebis (manajemen dan bisnis), 1(1), 9-17.

Colquitt, J. A., Jeffery, A. L., and Michael, J. W. (2012). Organizational Behavior. New York: McGraw-Hill.

Diputra, I. B., dan Riana, I. G. (2014). Pengaruh Budaya Organisasi dan Kepuasan Kerja Terhadap Motivasi Kerja Karyawan pada Hard Rock Hotel Bali. EJurnal Ekonomi dan Bisnis Universitas Udayana, 3(5), 276-288.

Estiawan, F. S. (2012). Analisis Sistem Manajemen Keselamatan dan Kesehatan Kerja (SMK3) Terhadap Kepuasan Kerja Karyawan, Studi pada PT PJB. UP Brantas (Perusahaan yang Bergerak pada Bidang Pemeliharaan dan Pembangkitan Listrik). Jurnal Fakultas Ekonomi Dan Bisnis, Universitas Brawijaya Malang, 1-17.

Gunawan, Ketut. (2010). Pembuktian Budaya Organisasi Pada Kepuasan Kerja. Jurnal Akuntansi, Manajemen Bisnis dan Sektor Publik, 6(3), 285-297.

Gupta, A. (2012). Impact of Occupational Health Safety on Employee Satisfaction. International Journal of Scientific Research. Indian Journal of Arts, 1(7), 118-120.

Gupta, Shobhna. (2013). A Comparative Study of Job Satisfaction in Public and Private Sector. Indian Journal of Arts, 1(1), 235-242.

Hermawan. (2015). Pengaruh Budaya Organisasi Terhadap Kepuasan Kerja Karyawan Studi Pada Pt. Bank Rakyat Indonesia (PERSERO) Kantor Cabang Kota Malang Kawi. Jurnal Administrasi Bisnis, 1(1).

Kurniawan, I. (2011). Pengaruh Keselamatan dan Kesehatan Kerja Terhadap Kepuasan Kerja Karyawan (Studi pada Karyawan Bagian Produksi PT Indohamafish Jembrana Bali). Jurnal Fakultas Ilmu Administrasi Universitas Brawijaya Malang, 1-11. 
Kurniawati, I. G., dan Sariyathi, K. (2015). Pengaruh Gaya Kepemimpinan Transformasional, Budaya Organisasi, Program K3 Terhadap Kepuasan Kerja Karyawan. E-Jurnal Manajemen Unud, 4(9), 2544-2561.

MacIntosh, E. W. (2009). The influence of Organizational Culture on Job Satisfaction and Intention to Leave. Journal of Sport Management Review, 13, 106-117.

Mangkunegara, A. A. P. (2013). Manajemen Sumber Daya Manusia Perusahaan. Bandung: Remaja Rosdakarya.

Mangkunegara, A. P. (2010). Perilaku dan Budaya Organisasi. Bandung: PT Refika Aditama.

Maqsood, Sumbal. (2013). Manager's Leadership Styles and Employee's Job Satisfaction. Journal of Human and Social Science Research, 1(2), 139-144.

Mathis, R. L. dan Jhon, H. J. (2010). Manajemen Sumber Daya Manusia. Jakarta: Salemba Empat.

Maulan. (2015). Pengaruh Keselamatan dan Kesehatan Kerja Terhadap Kepuasan Kerja Karyawan. Jurnal Administrasi Bisnis, 20(1).

Mehr, S. K. (2012). Relationship Between Job Satisfaction and Organizational Culture in Staffs and Experts of Physical Education Offices of Mazandaran Province. European Journal of Experimental Biology, 2(4), 1029-1033.

Nafrizal. (2012). Pengaruh Insentif, Motivasi Kerja, Gaya Kepemimpinan dan Budaya Organisasi Terhadap Kepuasan Kerja Serta Dampaknya pada Kinerja Personil Polri pada Satuan Kerja Biro Operasi Mapolda Aceh. Jurnal Manajemen Pascasarjana Universitas Syiah Kuala, 2(1), 52-67.

Odumeru, J. A., and Ifeanyi, G. O. (2013). Transformational vs transactional leadership theories: evidence in literature.

Petrik, A. dan Andreani, F. (2015). Analisis Pengaruh Gaya Kepemimpinan Transformasional Terhadap Kinerja Karyawan dengan Kepuasan Kerja Sebagai Variable Perantara di PT. Anugerah Baru Denpasar. AGORA, 3(2).

Purnama, C. (2013). Influence Analysis of Organizational Culture Organizational Commitment Job and Satisfaction Organizational Citizenship Behavior (OCB) Toward Improved Organizational Performance. International Journal of Business, Humanities and Technology, 3(5), 86-100. 
Purnomo, H., dan Muhammad, C. (2010). Pengaruh Gaya Kepemimpinan Terhadap Kepuasan Kerja Berdasarkan Motivasi Kerja pada Karyawan Administratif di Universitas Sebelas Maret Surakarta. Jurnal Manajemen Sumber daya Manusia, 4(1), 27-35.

Rahim, H. A. (2012). Pengaruh Kesehatan dan Keselamatan Kerja (K3) Terhadap Kepuasan Kerja Karyawan Unilever (Studi pada Tea Based Beverage (TBB) Factory Unilever Indonesia di Cikarang, Bekasi). Jurnal Program Studi Manajemen Fakultas Ekonomi Universitas Bakrie, 1-3.

Richard, H., Robert, G., dan Gordon, C. (2012). Leadership - Enhancing the Lessons of Experience - Memperkaya Pelajaran dari Pengalaman (7th ed.). Jakarta: Salemba Empat.

Rivai, Veithzal. (2010). Manajemen Sumber Daya Manusia untuk Perusahaan, Dari Teori ke Praktik. Jakarta: PT Rajagrafindo Persada.

Rizi, R. M. (2013). Relationship Between Leadership Styles and Job Satisfaction Among Physical Education Organizations Employees. European Journal of Sports and Exercise Science, 2(1), 7-11.

Rizondra. (2013). Pengaruh Motivasi Kerja, Gaya Kepemimpinan dan Budaya Organisasi Terhadap Kinerja Pegawai Dengan Kepuasan Kerja Pegawai Sebagai Intervening Variabel pada Dipertahortnakbun Kabupaten Pesisir Selatan. Jurnal Program Studi Magister Sains Manajemen Program Pascasarjana Universitas Bung Hatta, 1-17.

Robbins, S. P., dan Timothy, A. J. (2008). Perilaku Organisasi. Edisi ke- 12, Jakarta: Salemba Empat.

Rorimpandey, L. (2013). Gaya Kepemimpinan Transformasional, Transaksional, Situasional, Pelayanan dan Autentik terhadap Kinerja Pegawai Kelurahan di Kecamatan Bunaken Kota Manado. Jurnal Ekonomi Dan Bisnis.

Sageer, A. (2012). Identification of Variables Affecting Employee Satisfaction and Their Impact on the Organization. Journal of Business and Management, 5(1), 32-29.

Saputra, B. M. (2012). Pengaruh Gaya Kepemimpinan Transformasional Terhadap Kepuasan Kerja Melalui Kepercayaan Karyawan pada Atasan (Studi pada STT, STMIK, STBA dan Politeknik Cahaya Surya). Jurnal Otonomi, 13(1), 117-126.

Satyawati, N. M., dan Suartana, I. W. (2014). Pengaruh Gaya Kepemimpinan dan Budaya Organisasi Terhadap Kepuasan Kerja yang Berdampak pada Kinerja Keuangan. E-Jurnal Akuntansi Universitas Udayana, 6(1), 17-32. 
Sedarmayanti. (2011). Manajemen Sumber Daya Manusia. Bandung: PT Refika Aditama.

Sintha, K. (2013). Pengaruh Gaya Kepemimpinan Transformasional Terhadap Kepuasan Kerja Karyawan dan Komitmen Organisasi Pada PT. KPM. Jurnal Manajemen, Strategi Bisnis, dan Kewirausahaan, 7(2).

Supardi dan Syaiful, A. (2011). Dasar-Dasar Perilaku Organisasi. Yogjakarta: UII Press.

Supartha, W. G. (2010). Budaya Organisasi. Denpasar: Udayana University Press.

Susetyo. (2014). Pengaruh Budaya Organisasi Dan Lingkungan Kerja Terhadap Kepuasan Kerja Dan Kinerja Karyawan Pada PT. Bank Muamalat Indonesia Divisi Konsumer Area Cabang Surabaya. Jurnal Ilmu Ekonomi \& Manajemen, 1(1), 83-93.

Sutikno. (2014). Pemimpin dan Kepemimpin: Tips Praktis untuk Menjadi Pemimpin yang diidolakan. Lombok: Holistica Lombok.

Syauta, J. H. (2012). The Influence of Organizational Culture, Organizational Commitment to Job Satisfaction and Employee Performance (Study at Municipal Waterworks of Jayapura, Papua Indonesia). International Journal of Business and Management Invention, 11(1), 69-76.

Tawiah, K. A. (2011). Occupational Health and Safety: Key Issues and Concerns in Ghana. 2011. International Journal of Business and Social Science, 2(14), 119-126.

Thamrin, H. M. (2012). The Influence of Transformational Leadership and Organizational Commitment on Job Satisfaction and Employee Performance. Jurnal International Journal of Innovation, Management and Technology, 3(5), 566-572.

Thoha, Miftah. (2012). Kepemimpinan dalam Manajemen Suatu Pendekatan Perilaku. Jakarta: PT Raja Grafindo Persada.

Wicaksono, Triadhy. (2015). Analisis Pengarug Gaya Kepemimpinan Transformasional dan Kompensasi Terhadap Kepuasan Kerja Karyawan pada PT. Hymsa Indotraco Cirebon. Semarang: Universitas Diponogoro.

Wijanto, E. A. (2013). Pengaruh Leader Member Exchange Terhadap Kepuasan Kerja, Motivasi Kerja dan Komitmen Organisasional Karyawan Departemen Penjualan pada PT X. Jurnal Agora, 1(1), 1-10. 
E-Jurnal Manajemen, Vol. 9, No. 1, 2019 : 364-383

Yusnita, M. (2012). Pengaruh Program Keselamatan dan Kesehatan Kerja (K3) Terhadap Kepuasan Kerja Karyawan Bagian Produksi pada PT Keong Nusantara Abadi Natar Lampung Selatan. Jurnal Ilmiah, 5(1), 48-54. 